\title{
Are the Enterprises of Albanians in Macedonia Marginalized in the Economy of the Country?
}

\author{
Prof. Dr. Nasir Selimi \\ Lecturer of lliria College
}

\section{Doi:10.5901/ajis.2015.v4n1s2p191}

\begin{abstract}
The number of enterprises with Albanian owners, which are registered and function in Macedonia is not high, on the contrary it is far from structural national participation of the country. This unfavorable situation becomes even clearer if we also consider the size of enterprises owned by Albanians of this country. In fact Albanian entrepreneurs are owners of small and medium enterprises while the numbers of big enterprises that function in Macedonia are not owned by them. This is even more present in enterprises which have as a main activity the reproduction of minerals, minerals extraction, in pharmaceutics, communication services, banking and security services. Beside this fact, Albanians which live and work in Macedonia orientate their business activity mainly on retail trade, offering hotelier services, on small production, and especially on small businesses. Without a doubt one of the main reasons for this is the privatization of social enterprises, which was done in Macedonia during the transition period. Albanians were marginalized from this process and they remain excluded on the portioning process of the social capital, which were an integral part of that country.
\end{abstract}

Keywords: Enterprises, Transition, Privatization, Export, Trading Balance.

\section{Macedonia's Economy Marks Growth, but not Economic Development}

Macedonia's economy in 2014 recorded economic growth of 3. 2\% (The World Bank, Annual Report 2014). This represents the largest increase this year as part of the Western Balkan countries. This growth is mainly based on the growth of the construction industry, agriculture as well as a significant rise in exports of goods. During 2014, Macedonia was more fortunate compared to neighboring countries because the country's economy did not suffer extensive damage from flooding as its neighbors did. The forecast for 2015 is a growth of $3.5 \%$.

The annual report warns that Macedonia should be careful in future years and work more on strengthening the real sectors of the economy. Government representatives should review the country's economic policy, especially in a more fair redistribution of income in order to decrease the unemployment rate and to reduce the unemployment rate. This applies even more so when we consider the fact that Macedonia's society for years in the past had the highest rate of unemployment in the region and reached $30 \%$, the same figure as has the number of the poor. Obviously economic growth of 3. $2 \%$ is not sufficient to affect the reduction of unemployment and poverty in the country. We estimate that the number of unemployed in the country and the poor would be reduced significantly if the economic growth would reach at least 6-7\%. Another positive impact would be the redistribution of income from growth to society, i. e. whether it would be more just and humane.

Fairer distribution of income in the future will certainly impact in reducing the number of poor and unemployed. This would sooth the situation where now the rich are getting richer and the poor poorer. The economy of a country can have economic growth, but if this growth does not benefit the broad masses of the population, then its economic development policy is unsuccessful (J. Stiglitz, through BZ Vest, 2015). This also occurred in Macedonia; this year only five firms that operate in the Macedonian economy have achieved $16 \%$ of the total profit.

Regarding external debt of Macedonia, it is among the countries with average debt. In 2014 its debt came to be 45 . $7 \%$ of the GDP, but it is worrying that the recent debt growth rate is high. So in the future the government of the country should be careful in government spending, especially in financing projects such as the nonproductive "Skopje 2014". The current year budget is projected the largest ever, 2. 955 billion USD with a deficit of 3. 5\%. The budget has a more social character than development, because the dominant part of the costs, $89 \%$, is transfers, while only $11 \%$ are capital investments.

The banking system in Macedonia is not helpful enough to the real economy. In 2014 it has credited only 68 million Euros while the amount held in securities was 1.5 billion euros. Macedonia's government must quickly relinquish this 
amount and allow the real sector to function normally.

Foreign direct investments for 2014 were planned in the amount of 350 million USD, while the amount achieved was 220 million USD (Report of NB of RM, 2015). In fact in terms of attracting FDI, Macedonia for years ranks in the bottom of the Western Balkan countries. (Nasir Selimi, 2014). The most important factors that have contributed to a very low FDI in Macedonia are: corruption in the government administration of Macedonia, frequent changes of domestic legislation, lack of infusion deficit, poor infrastructure, the functioning of the rule of law, etc.

\section{The Polog Region, although Rich in Resources has Lower Economic Performance}

Undoubtedly proper scientific analyses are based on statistical data processing and analysis of various statistical indicators. Although our efforts to collect statistical data did not fail, it was not fully implemented successfully. Seldomly an author of a scientific paper can be faced with a problem of this nature. The reasons are many and of various natures. State institutions witch simultaneously have a legal obligation to be transparent and to publish data for public use, do not do this. They are even hesitant to do so on issues such as ours. However, the data that is available have their weight and relevance. Therefore these can be processed and generate conclusions and recommendations in which a modest contribution to science can be made. In this regard, our analysis will rely on different economic methods which mostly will focus on the deductive method, inductive, and analytical comparison.

According to the latest census of the population, a total of over 2,000,000 inhabitants live in Macedonia (State Census Bureau, 2003).

Table 1. Basic Demographic Indicators as of 30. 06. 2013 in (000)

\begin{tabular}{|l|c|c|c|c|c|c|c|c|c|}
\hline & $\begin{array}{c}\text { Republic of } \\
\text { MK }\end{array}$ & $\begin{array}{c}\text { Vardar } \\
\text { Region }\end{array}$ & $\begin{array}{c}\text { East } \\
\text { Region }\end{array}$ & $\begin{array}{c}\text { SE } \\
\text { Reg }\end{array}$ & $\begin{array}{c}\text { SW } \\
\text { Region }\end{array}$ & $\begin{array}{c}\text { Pelagonia } \\
\text { Region }\end{array}$ & $\begin{array}{c}\text { Polog } \\
\text { Region }\end{array}$ & $\begin{array}{c}\text { NE } \\
\text { Region }\end{array}$ & $\begin{array}{c}\text { Skopje } \\
\text { Region }\end{array}$ \\
\hline Total popula. & 2.058 & 154 & 179 & 173 & 221 & 234 & 316 & 175 & 606 \\
\hline Male & 1.031 & 78 & 91 & 87 & 111 & 117 & 159 & 89 & 299 \\
\hline Female & 1.027 & 75 & 89 & 85 & 110 & 117 & 157 & 86 & 307 \\
\hline Density & 82.6 & 38.1 & 50.7 & 63.2 & 66.3 & 49.5 & 130.8 & 75.9 & 334.2 \\
\hline
\end{tabular}

Source: R. of Macedonia, State Statistical Office, Regions of the R. of Macedonia, 2014

From the table above we can see that Macedonia's population is divided by regions, a total of 8 regions. The most populated region in Macedonia is the Skopje region with a total of 606 thousand inhabitants. The second region is the region of Polog with a population of 159 thousand inhabitants, or 15. 3\% of the total population, while the following is the Pelagonia with a total of 117 thousand people or $11.3 \%$.

The following analysis will account of two regions, the Polog and Pelagonia, which rank second and third respectively in the republic. The Polog region includes the municipalities of Tetovo, Gostivar, Vrapxhishtit, Bogovinje, Brvenica, Jegunovce, Zhelina, Mavrovo and Rostuša, and Tearce. In this region the dominant structure of the population is Albanian. Pellagogina Region includes the municipalities of Bitola, Demir Hisar, Krivogastani, Krusevo, Mogila, Novaci, Prilep and Resen. In these regions the dominant structure is Macedonian.

Table 1. Activity rates of the population aged 15 years and over, 2013 in (000)

\begin{tabular}{|l|c|c|c|c|c|c|c|c|c|}
\hline & $\begin{array}{c}\text { Republic } \\
\text { of MK }\end{array}$ & $\begin{array}{c}\text { Vardar } \\
\text { Region }\end{array}$ & $\begin{array}{c}\text { East } \\
\text { Region }\end{array}$ & $\begin{array}{c}\text { SW } \\
\text { Reg. }\end{array}$ & $\begin{array}{c}\text { SE } \\
\text { Reg. }\end{array}$ & $\begin{array}{c}\text { Pelagonia } \\
\text { Region }\end{array}$ & $\begin{array}{c}\text { Polog } \\
\text { Region }\end{array}$ & $\begin{array}{c}\text { NE } \\
\text { Region }\end{array}$ & $\begin{array}{c}\text { Skopje } \\
\text { Region }\end{array}$ \\
\hline Working age population & 1.672 & 126 & 150 & 180 & 141 & 189 & 257 & 140 & 487 \\
\hline Activity rate & 57.2 & 60.7 & 61.0 & 56.2 & 69.9 & 64.4 & 46.6 & 54.2 & 55.3 \\
\hline Employment rate & 40.6 & 42.6 & 49.1 & 35.6 & 56.8 & 50.1 & 31.0 & 29.9 & 39.1 \\
\hline Unemployment rate & 29.0 & 29.8 & 19.5 & 36.7 & 18.8 & 22.2 & 33.6 & 44.9 & 29.3 \\
\hline
\end{tabular}

Source: R. of Macedonia, State Statistical Office, Regions of the R. of Macedonia, 2014

Based on the table above we can see that the region of Polog has employment rate lower than the average in the country by 9.6 points. In comparison with the Pelagonia region, Polog has an employment rate lower by 19.1 points. The 
unemployment rate is also different. Unemployment in the region of Polog is greater than the national average by 4. 6 points, while if we compare with the Pelagonia region, the unemployment rate is higher Pollog by 11.4 points.

One of the most important macroeconomic indicators is GDP. This indicator shows the market value of final goods and services in one place for a specified period. (Mankiw, Principple of Economics, 2012). Below we present table 2 which reflects the creation of GDP / per capita in some years by region.

Table 2. Gross Domestic Product per capita in (000 denars)

\begin{tabular}{|c|c|c|c|c|c|c|c|c|c|}
\hline & $\begin{array}{c}\text { Republic of } \\
\text { MK }\end{array}$ & $\begin{array}{c}\text { Vardar } \\
\text { Region }\end{array}$ & $\begin{array}{c}\text { East } \\
\text { Region }\end{array}$ & $\begin{array}{c}\text { SE } \\
\text { Reg }\end{array}$ & $\begin{array}{c}\text { SW } \\
\text { Region }\end{array}$ & $\begin{array}{c}\text { Pelagonia } \\
\text { Region }\end{array}$ & $\begin{array}{c}\text { Polog } \\
\text { Region }\end{array}$ & $\begin{array}{c}\text { NE } \\
\text { Region }\end{array}$ & $\begin{array}{c}\text { Skopje } \\
\text { Region }\end{array}$ \\
\hline 2010 & 211 & 206 & 207 & 156 & 220 & 225 & 99 & 109 & 315 \\
\hline 2011 & 223 & 228 & 207 & 162 & 258 & 228 & 106 & 145 & 321 \\
\hline 2012 & 222 & 233 & 205 & 158 & 244 & 211 & 98 & 151 & 332 \\
\hline
\end{tabular}

Source: R. of Macedonia, State Statistical Office, Regions of the R. of Macedonia, 2014

A higher gross domestic product per capita compared to the average of the Republic of Macedonia was recorded in the Skopje Region with an index of 149. 4, the Southeast Region with an index 109. 7, and the Vardar Region with an index 104. 6. All other regions had gross domestic product per capita below the average of the Republic of Macedonia. The smallest gross domestic product per capita compared to the average of the country was recorded in the Polog Region, with an index of 43. 9.

The Polog region, although the number of inhabitants is the second at the country it is ranked last for the creation of goods and services. This macro-economic indicator, GDP, shows clearly the low level of economic development of its region. From this we understand that the resources which this region has are not used even approximately compared with other regions. The young age of the population, the age quotient youngest in the country, 35. 8 year old (State Statistical Office, Regions of RM, 2014) is left at the mercy of chance where a large number of young people migrate to foreign countries to seek a best prospect in the future.

Production capacities in this region are scarce, with state officials not caring about capital investments. Manufacturing facilities by a foreign investor are slim, even by those who only develop activities in the sphere of trade and services. Years and decades of a rumored project for a free trade area in the region have gone by, but to this date nothing has come of it. The fact that this region creates GDP in the amount of 98 million or only $43.9 \%$ of the average GDP of the country clearly says a lot as well.

Despite this Pelagonia region with the number of population smaller than that of Polog for approximately 42 thousand inhabitants, in 2013 it achieved the value of total GDP 211 million denars which is more than double compared with that the Polog. This situation is the same for all the years of analysis without having any relevant change each year.

Small businesses in any society play an important role in overall economic development of the country. They are not by chance called "the backbone of the economy" (A. Cepani, 2003, Tirana). Undoubtedly Macedonia's economy also depends heavily on the advancement and development of entrepreneurship and small business.

Table 1. Number of active business entities by number of persons employed, 2013

\begin{tabular}{|c|c|c|c|c|c|c|c|c|c|}
\hline Nr. of emalo. & $\begin{array}{c}\text { Republic } \\
\text { of MK }\end{array}$ & $\begin{array}{c}\text { Vardar } \\
\text { Region }\end{array}$ & $\begin{array}{c}\text { East } \\
\text { Region }\end{array}$ & $\begin{array}{c}\text { SW } \\
\text { Region. }\end{array}$ & $\begin{array}{c}\text { SE } \\
\text { Region }\end{array}$ & $\begin{array}{c}\text { Pelagonia } \\
\text { Region }\end{array}$ & $\begin{array}{c}\text { Polog } \\
\text { Region }\end{array}$ & $\begin{array}{c}\text { NE } \\
\text { Region }\end{array}$ & $\begin{array}{c}\text { Skopje } \\
\text { Region }\end{array}$ \\
\hline $\mathbf{0}$ & 4.415 & 295 & 254 & 284 & 295 & 323 & 217 & 139 & 2.608 \\
\hline $1-9$ & 60.599 & 4.810 & 4.894 & 6.433 & 5.247 & 7.280 & 6.620 & 3.760 & 21.555 \\
\hline $10-19$ & 2.989 & 181 & 281 & 241 & 273 & 340 & 187 & 175 & 1.311 \\
\hline $20-49$ & 1.787 & 122 & 174 & 151 & 146 & 169 & 126 & 145 & 754 \\
\hline $50-249$ & 1.291 & 105 & 175 & 103 & 111 & 135 & 79 & 79 & 504 \\
\hline $250+$ & 209 & 13 & 18 & 7 & 11 & 21 & 7 & 5 & 127 \\
\hline Total & 71.290 & 5.526 & 5.796 & 7.219 & 6.083 & 8.268 & 7.236 & 4.303 & 26.859 \\
\hline
\end{tabular}

Source: R. of Macedonia, State Statistical Office, Regions of the R. of Macedonia, 2014

In the table above we show that the total number of enterprises that are active in the Republic of Macedonia in 2013 is 
71,290 . The Polog region with the number of 7236 represents $10.1 \%$ which is nevertheless smaller than the share in the overall population of $15 \%$. If this figure is compared with the number of enterprises in the region of Pelagonia, then we will see that this is 1032 lower. Note that the number of enterprises with more than 250 employees is very small, only 7 , that is three times smaller than the same number of enterprises in the Pelagonia region.

Based on the analysis we concluded that the largest number of enterprises correspond to the wholesale and retail trade (35.7\%); followed by the processing industry (11. 1\%), transport and storage (8. 5\%), Professional, scientific and technical (8. 2\%), construction (6. 1\%), accommodation and food services (6. 3\%), health and social insurance (4. 7\%), etc. With a smaller percentage included defense sectors and public administration (0.4\%), mining and quarrying (0.2\%), electricity supply, gas, heating and air conditioning supply (0.2\%), etc.

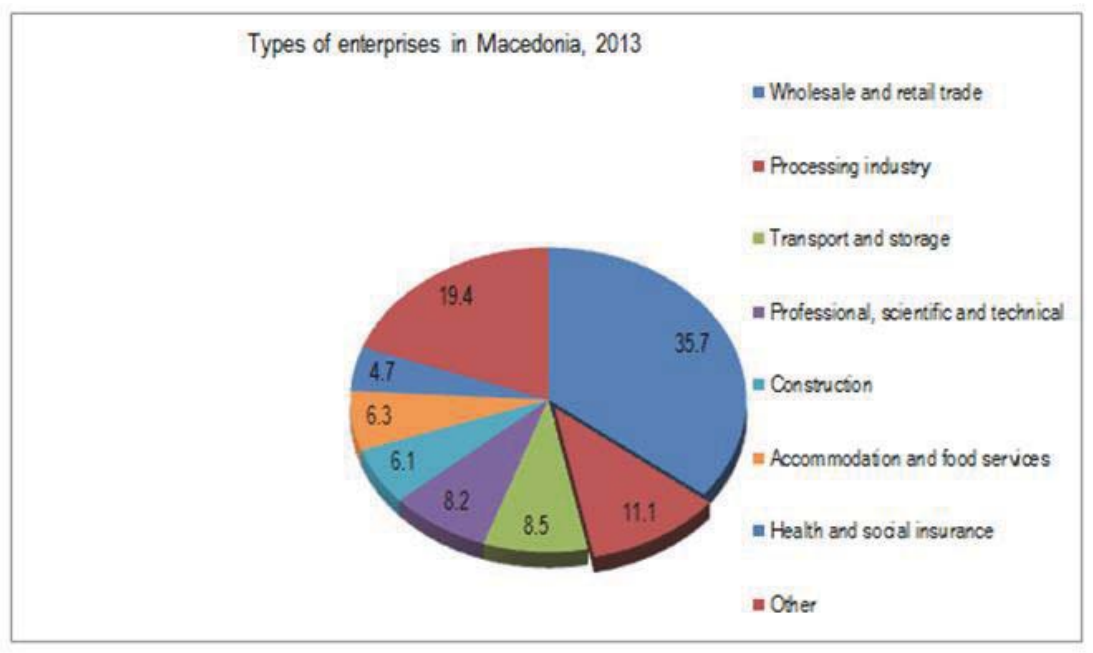

Source: Compiled by the author based on data from the Statistical Office of the Republic of Macedonia

The Number of enterprises in the region of Polog is not only small in number, but it structure itself is also small. Since the collapse of the former socialist system, no new large enterprises were created in this region. Those which survived the transition are a symbolic number, but their financial situation is weak. In the following we give an overview of the number of active enterprises operating in the region Pollog in a period of 2008-2013.

Tabele nr. 6 The number of companies active in the region of Polog

\begin{tabular}{|c|c|c|c|c|c|c|}
\hline & 2008 & 2009 & 2010 & 2011 & 2012 & 2013 \\
\hline 0 & 334 & 323 & 712 & 311 & 302 & 217 \\
\hline $1-9$ & 5.417 & 5.944 & 6.211 & 6.414 & 6.592 & 6.620 \\
\hline $10-49$ & 210 & 226 & 268 & 288 & 306 & 313 \\
\hline $50-249$ & 79 & 75 & 82 & 75 & 79 & 79 \\
\hline $250+$ & 10 & 9 & 7 & 6 & 6 & 7 \\
\hline Total & 6.050 & 6.577 & 7.280 & 7.100 & 7.285 & 7.236 \\
\hline
\end{tabular}

Source: Compiled by the author based on data from the Statistical Office of the Republic of Macedonia

Data on active enterprises show that the largest percentage of employees are in companies with 1 to 9 employees with 91. 48\%; enterprises that conceal the number of employees with 2. 99\%; enterprises with 10 to 49 employees with 4. 3\%; enterprises with 50 to 249 with 1. 09\%; enterprises with over 250 employees with 0. 096\%. (www. stat. gov. mk). The establishment of new enterprises during the year is important for the development of small business. The following table will show the number of newly registered enterprises in 2012. 
Table 2. Number of enterprise creation by statistical regions, 2012

\begin{tabular}{|c|c|c|c|c|c|c|c|c|c|}
\hline & $\begin{array}{c}\text { Republic of } \\
\text { MK }\end{array}$ & $\begin{array}{c}\text { Vardar } \\
\text { Region }\end{array}$ & $\begin{array}{c}\text { East } \\
\text { Region }\end{array}$ & $\begin{array}{c}\text { SW } \\
\text { Reg }\end{array}$ & $\begin{array}{c}\text { SW } \\
\text { Region }\end{array}$ & $\begin{array}{c}\text { Pelagonia } \\
\text { Region }\end{array}$ & $\begin{array}{c}\text { Polog } \\
\text { Region }\end{array}$ & $\begin{array}{c}\text { NE } \\
\text { Region }\end{array}$ & $\begin{array}{c}\text { Skopje } \\
\text { Region }\end{array}$ \\
\hline Total & 8.329 & 607 & 592 & 885 & 583 & 1000 & 834 & 535 & 3.293 \\
\hline
\end{tabular}

Sourse: R. of Macedonia, State Statistical Office, Regions of the R. of Macedonia, 2014

According to the data from the State Statistical Office, the number of enterprise created in the Republic of Macedonia in 2012 was 8329. The data on the structure of enterprise creation by statistical regions show that the highest share of 39. $5 \%$ belongs to the Skopje Region, while the Northeast Region had the lowest share of $6.4 \%$.

This indicator also informs us that the number of firms registered in Polog region is smaller than that in the Pelagonia region. Given the number of people living in this region, the number of enterprises should be larger. In relation to this, the President of the Chamber of Commerce of North-Menderez Kuqi says: "All governments without exception have not taken concrete steps to help business development in this region. This is due to the inadequate policies in the past that have not paid a great attention to balanced regional development. Meaning that in Pollog important issues such as infrastructure, Corridor 8 and other investment policies have been neglected " (Koha, 2015).

Export together with foreign direct investment is one of the motor forces of economic development of a country. In the modern economy export is not the privilege of only large enterprises, SMEs today are increasingly aware that export not only generates significant revenue, but also ensures a better perspective for the future.

The following table gives an overview of exports of goods and services in Macedonia by region in a period of four years.

Table 2. Export in the period 2009-2013

\begin{tabular}{|c|c|c|c|c|c|c|c|c|c|}
\hline & $\begin{array}{c}\text { Republic of } \\
\text { MK }\end{array}$ & $\begin{array}{c}\text { Vardar } \\
\text { Region }\end{array}$ & $\begin{array}{c}\text { East } \\
\text { Region }\end{array}$ & $\begin{array}{c}\text { SW } \\
\text { Reg }\end{array}$ & $\begin{array}{c}\text { SW } \\
\text { Region }\end{array}$ & $\begin{array}{c}\text { Pelagonia } \\
\text { Region }\end{array}$ & $\begin{array}{c}\text { Polog } \\
\text { Region }\end{array}$ & $\begin{array}{c}\text { NE } \\
\text { Region }\end{array}$ & $\begin{array}{c}\text { Skopje } \\
\text { Region }\end{array}$ \\
\hline $\mathbf{2 0 0 9}$ & 100.0 & 12.4 & 14.0 & 2.3 & 11.5 & 7.6 & 3.1 & 2.3 & 46.8 \\
\hline $\mathbf{2 0 1 0}$ & 100.0 & 16.3 & 12.2 & 1.9 & 10.3 & 6.2 & 2.5 & 1.9 & 48.7 \\
\hline $\mathbf{2 0 1 1}$ & 100.0 & 15.8 & 10.6 & 1.7 & 8.3 & 6.0 & 3.2 & 1.7 & 52.7 \\
\hline $\mathbf{2 0 1 2}$ & 100.0 & 16.8 & 11.0 & 1.9 & 8.5 & 6.4 & 2.7 & 1.6 & 51.2 \\
\hline $\mathbf{2 0 1 3}$ & 100.0 & 15.0 & 10.7 & 2.1 & 9.3 & 7.4 & 3.7 & 1.6 & 50.3 \\
\hline
\end{tabular}

Source: R. of Macedonia, State Statistical Office, Regions of the R. of Macedonia, 2014

According to the headquarters of the business entities, in 2013, the biggest exports (USD 2136 million) as well as the biggest imports (USD 4482 million) were registered in the Skopje Region. The business entities with headquarters in the Northeast Region had the lowest volume of external trade. The Polog region as a result of previous parameters normally has poor results. It accounts for only 3. 7\% (2013) of total exports which is not in proportion with the number of inhabitants. So the region with 15. 3\% of the overall population of the country, exports only 3. $7 \%$ of the total exports. Whereas the Pelagonia region has two times that number and reaches $7.4 \%$ of the overall exports.

\subsection{The overall evaluation of enterprise activity of the Albanians in Macedonia}

According to economic theory, economic activities do not accept marginalization, regional restrictions, those national or religious. However, in everyday life in certain countries they not only appear as a phenomenon, but also becomes a necessity. When this phenomenon becomes common by the state, it must be considered as an economic discrimination. Such a thing we had in this country in the past, but it still remains in the present situation in Macedonia.

In Macedonia, according to ECNWM there are over 3200 (OEVPM, catalog, 2015) companies whose owners are of Albanian ethnicity. These entrepreneurs have operated since Macedonia's independence, but none of these, unlike other domestic, companies are owners of large enterprises whose activity is in the mining, metals, pharmaceutical, hospitals, insurance and bank industries. Only by the sacrifices made by them and their families, selfless work and great commitment to the work were they able to keep their businesses alive. The Government of Macedonia during the transition phase has not seen their business with good eyes, and there are numerous known occasions when it together 
with its agencies and institutions have been an obstacle to their development and strengthening. Albanians companies often played the role of mediator between the Macedonian companies and Albanian consumers. Terms of the country to a free competitive market have been in their disfavor, starting from their taxation up to consumers sales.

Albanian companies are not part of the great success and this can clearly be seen from the fact that there are no Albanian companies operating in any natural monopoly sectors such as telecommunications, energy, banking, leasing, etc. Another argument that speaks in favor of this view is the fact that within the 100 largest exporting enterprises in Macedonia only 2 or 3 of them are Albanian-owned enterprise. (OEM, 100 najgolemi pretprijatia vo RM, 2014).

A large percentage of firms owned by Albanians are either the small or medium sized. This is mostly small businesses in retail trade, manufacturing and in the services sector. But, unfortunately, these remain only on the margins and are nowhere near the dominant positions in the Macedonian market. On the occasion of the ten best companies for 2014 by ECNWM, the economy minister stated: ". . . the turnover of these 100 companies listed as the most successful, last year recorded 524 million Euros, which makes up 3\% of total turnover in the country, which is 17 billion and 340 million Euros. In the meantime, the number of employees increased by 5600 and that in his opinion clearly proves the growth and development of these companies in the right direction " (http: //www. economy. gov. mk/vesti/4381. html ). This fact suggests that the Albanians which participate nationally with $25.8 \%$ of the population structure, generate general circulation in the country by a little more than $3 \%$.

Marginalization of Albanian business in the independent Macedonia started during the privatization of state property. In fact, the process of privatization of state enterprises began when Macedonia was part of the ex Yugoslavia and the so-called "Law of Markovic". The essence of this was that companies can be privatize only to employees of enterprises through internal stock, but not other individuals outside the enterprise. Very few state enterprise workers were Albanians.

The percentage of Albanian employees in state enterprises was symbolic and did not exceed 3\%. (A. Bexheti, 2004). This method of privatization did not suit the Albanian population, and it deprived them the right to share its social wealth which we had built together with other nations for nearly half a century.

Manipulations and similar embezzlement behavior occurred even with new laws in Macedonia pluralistic and independent state, during which the "aerobics calculated and accounting, the financial engineering design through managerial forms and payment deadlines extended" (A. Bexheti , 2010). Albanians continued to remain out of the process of privatization of state enterprises also later when large and public enterprises were privatized. They were simple voyeurs, but not active actors in this crucial process for the economy and society in general.

Presence of corruption is another segment which is quite damaging to the business of Albanians in Macedonia. Lack of Albanian representatives in key economic institutions of the country and the rule of law malfunction resulted in a more difficulty economic activity. So the entrepreneurs had many barriers in obtaining permits, certificates, or any other necessary documents. Permanently a number of state administration for someone creates favoritism and unequal conditions in the market. Rather surprisingly, this business has enough indications that it is not equal, even during the difficult and selective loanings by banks that operate in the country.

The Government of Macedonia only in the last decade has severely damaged the Albanian business. They "have destroyed millions of Albanian owned businesses and severely damaged Albanian businessmen. All this is done by the government in order to have the media effect, as we had the occasion to listen to audio recordings which published SDSM leader Zoran Zaev. Following Almakos reminds us about the case of the collapsed facilities "Cosmos" in Skopje "Lovec" in Gostivar and "Chinese Wall" in Skopje, which is actually known as "Park Residence" (Almakos, March 2015).

The marginalization and discrimination of the Albanian business is not lacking in economic policies, even those of strategic Macedonia. So, for example delays in the construction of road transportation are made in the majority Albanians region, the regional development policy is not equal to the country as a whole, foreign direct investment are oriented in geographic areas where Macedonians live, free trade zones and industrial production is microscopic in the region of Western Macedonia, agriculture in this region has been neglected by bypassing the state and giving substitutional options, etc.

Today, as we are writing this paper, the media is broadcasting the current Prime Minister of the government of the country inaugurates an industrial area in Vinica, a district with a population of pure Macedonian nationality, which currently possesses five companies and is expected to gain another eleven by the end of the year. Despite this, the western part of the country has not yet seen such a function.

"Any disturbance of this type has an impact on every state, namely on its economy. We have witnessed such shocks in some neighboring countries which have not been immune to these conditions. In the local territory, our companies have become accustomed to these conditions, but this will not reflect equally on foreign investors, 
unfortunately, the impact will be bad. I myself have had an actual meeting with an actual investor who wanted to invest in the free economic zone in Tetovo, but pulled out of the deal wanting to invest at a better time, which is a direct consequence of situation in the country, "says businessman Menderes Kuqi, the Chamber of Commerce of North Macedonia. (Aneta Dodevska, portalbe, March 2015).

\section{Conclusion and Recommendation}

An Albanian business which takes place in Macedonia since the independence of this country is not only marginalized, but it is damaged in various forms. While their colleagues receive support from the state and its institutions, they stumble to develop and expand the business.

On the basis of the above exposition we can conclude that the Albanians are not incidentally excluded from the economic participation, but they are systematically and structurally outside the economic system.

The marginalization of Albanian business has begun early in former Yugoslavia, but in independent Macedonia it began with the privatization of state enterprises. Privatization in Macedonia was conducted in one of the most bizarre and unfair forms. Shares of enterprises can buy them only a fraction of the population, i. e. those who were employed, also the most privileged. Exemption from this process continued until the final privatization, when managers and other leaders of enterprises robbed a common property that was set up together for decades.

The Albanian business in Macedonia, however, was built with many commitments and sacrifices during these years of transition. Although it faces many trials and obstacles, it nevertheless moves towards success and greater results. The conditions and circumstances in which Albanians lived in Macedonian forced them to deal with small business development early on.

Today Albanian business in Macedonia faces various problems. Albanian entrepreneurs are given alternatives by representatives of state bodies, bribes are asked for the registrations and documents. Giving bribes and corruption can hardly be defended in an enterprise. Political, economic and state strategy does not support the overall development of the country. The fact that the level of infrastructure and other economic prerequisites in the western part of the country is neglected, shows that entrepreneurs of this area are discriminated against.

Overcoming and improving this situation is in need as soon realized investments in road and rail infrastructure, which businesses will be more competitive in order to improve the business environment and the satisfaction of conditions as much local and foreign investors explore the possibility of investment, which would be realized half of business application.

Prevention of this economic discrimination that you become Albanians can be done if: first and foremost function rule of law and is the same for all its citizens, the union of Albanian political class to important national issues, employment of new staff and the capable and professionals in all important places in government, membership into EuroAtlantic structures, etc. $\mathrm{s}$.

Pollog region has never missed private initiative and entrepreneurial spirit, but lacked a greater institutional support and state to businessmen from this area. Residents of this area have entrepreneurial spirit and private initiatives. They are known as good entrepreneurs, have long tradition, but in comparison with the effect of this action policymakers must respond to the economic policy.

\section{References}

Bexheti, A. (2006) "Një dekadë e mendimit ekonomik dhe politik" Logos, Shkup World Bank (2014) "The World Bank, Annual Report 2014", Washington D. C.

Zdravkovska, B (2015), "GDP", Vest, Skopje

NBM (2015), "Mesecen Izvestaj" Skopje

Selimi, N (2012), "Macedonia and Foreign Direct Investments" In International Journal of Academic Research in Accounting, Finance and Management Sciences Volume 2, Issue 4, pp. 306-317. Reading, Berkshire, UK, 12 / 2012. ISBN 2225-8329

State Statistical Office (2006), State Census Bureau 2003, Skopje

State Statistical Office, (2014), Regions of the R. of Macedonia 2014, Skopje

Cepani, A, (2003), "Biznesi i vogël dhe sipërmarrësia", Pegi, Tiranë

Koha (2015),

Mankiw, (2007), "Essentials of Economics"Fourth Edition, Thomson, Mason, $\mathrm{OH}$

OEVPM, (2015), Catalog, 2015

Dodevska, A, (2015), Portalbe 
